\title{
Serum Bicarbonate Measurement
}

National Cancer Institute

\section{Source}

National Cancer Institute. Serum Bicarbonate Measurement. NCI Thesaurus. Code C61022.

A quantitative measurement of the amount of bicarbonate present in a sample of serum. 